\title{
Why Indonesia Maintain Capital Punishment?
}

\author{
Ahmad Irzal Fardiansyah \\ Faculty of Law, Universitas Lampung, Indonesia, Email: ahmad.irzal@fh.unila.ac.id
}

Submitted: April 28, 2020; Reviewed: June 2, 2020; Accepted: October 8, 2020

\begin{tabular}{ll}
\hline \multicolumn{1}{c}{ Article Info } & \multicolumn{1}{c}{ Abstract } \\
\hline Keywords: & The death penalty in Indonesia is still maintained to \\
Death Penalty, Indonesia, & combat crime within the Indonesian criminal law \\
Maintain. & reform. Although many states have it removed, \\
Indonesia would have the sole discretion to keep it. & Despite the opposition, the death penalty application \\
10.25041/fiatjustisia.v15no1.1904 & still has a juridical and sociological basis, so it is still \\
& legal to be maintained. Indonesia itself has \\
overshadowed the death penalty with a form of & legality according to international law so that the \\
position of Indonesia that still maintain the death & penalty cannot be blamed. Moreover, sociologically, \\
Indonesian people still accept those who commit an \\
offence who may have profound implications that \\
could lead to the death penalty. This issue is what \\
became the basis for lawmakers in Indonesia to keep \\
it. This research uses the doctrinal method to examine \\
various regulations regarding capital punishment and \\
non-doctrinal to understand the community's situation \\
related to the existence of capital punishment in \\
Indonesia. \\
The death penalty is a more effective deterrent and \\
therefore prevents crime better. With the death \\
penalty, others were about to commit a similar crime \\
is expected not to commit the crime. The death penalty \\
is more effectively immobilizing offenders. \\
Perpetrators, in principle, still manage to have the \\
desire to commit the crime again after release. The \\
death penalty for perpetrators of crimes is not a \\
violation of human rights, but rather to respect human \\
rights itself, namely for victims of crime. The setting \\
and the application of the death penalty in Indonesia \\
until now is still needed. They are considering that \\
there are still many crimes that undermine humanity's \\
values or the crimes that harm the State and \\
crackdown on corruption in society.
\end{tabular}




\section{A. Introduction}

Capital punishment has a long history - for most of the last millennium, it was the primary judicial sanction in England, a country whose institutions have influenced many others. British imperial expansion into America and Australia carried with it a legal code founded on the death sentence. ${ }^{1}$ The death penalty in the Code of Penal (Penal Code) Indonesia is currently in effect, and the death penalty becomes even the main staple criminal because the criminal selection numbers are placed first in the order of the type of criminal. A death penalty is an option that can be given along stipulated in the legislation. This is in accordance with the principles enunciated in the Universal Declaration of Human Rights (UDHR) and the International Covenant on Civil and Political Rights (ICCPR), which states that it should not penalize people arbitrarily. The setting there is an effort to eliminate forms of arbitrariness, because basically when the rules made it an agreement of a nation to protect themselves from crime there, which included the arbitrary actions executed by someone not because of crime but rather due to the interest of eliminating political opponents and so on. Philosophically, punishment is not concerned with what the penalty should be given for any crime but rather refers to the fundamental questions about the rights and wrongs of punishment itself. ${ }^{2}$ This means that it invites us to understand that the death penalty administration cannot be seen in the context of another infringement because, in principle, there is also a violation of others' rights to the crimes committed. In Roy's view, there are three different theories about this: First, the theory of prevention is based on the concept that, if the consequences of committing a crime outweigh the benefits of the crime itself, the individual would be deterred from committing crimes.

In this case, the criminals are punished for setting an example to others to prevent them from repeating similar crimes. The main drawback of this approach is that here we are using criminals as a means to teach others. This sometimes leads to severe penalties for minor offences. Second, the theory of reform. The object of this theory is to reform a person through punishment and ultimately making the law-abiding citizens. Nowadays, many people like the Right Honor Judge Mackenzie supports this school of thought because it is humanitarian. Required that we must assume thieves and criminals as our brothers and sisters, and crime as a disease in which the latter is the victim of a disease and needs to be healed. Third, retributive theory. "According to this theory, the purpose of punishment is to make the defendant aware that he had to suffer because of wrongdoing. This echoes the proverb "eye for an eye and a tooth for a tooth. If you are robbed, you rob yourself, if you are slandered,

\footnotetext{
${ }^{1}$ Janet Chan and Deborah Oxley, "The Deterrent Effect of Capital Punishment : A Review of the Research Evidence", Crime and Justice Bulletin, no. 84 (2004): 1-24, 2.

${ }^{2}$ Gargi Roy, "Is Capital Punishment Acceptable?", International Journal of Humanities and Social Science 4, no. 2 (2014): 95-98, 95.
} 
you are slandering yourself, if you hit him, you attack yourself, and if you kill her, you kill yourself. The third philosophy value above is basically the death penalty, after being executed, logically imply no person convicted; therefore, by definition, that person will not be aware of the punishment at the time of execution. However, the penalty must be accompanied with the convicts' awareness or understanding of the importance of punishment, as far as we accept the traditional concept of the person as agent to whom the moral and legal penalties can be imposed. ${ }^{3}$

In this case, the convicts' awareness is about knowledge and understanding of what would be given to them, which is a death penalty. The convicts' awareness is built upon the law enforcement process in accordance with the legislation in force, so there is no arbitrariness in it. As a country that still has the death penalty, Indonesia certainly does not ignore the things mentioned above, despite continuing conflicts. In the framework of criminal law reform in the planned change of the Indonesian Penal Code, the death penalty remains reserved for offenders. Despite the change in principle, which initially was the principal criminal, but in the plan to change the Criminal Code, it is placed as an option, with more criteria. This suggests there are also developments in Indonesian society, causing a shift in the death penalty status. Nevertheless, if someday, the death penalty is no longer wanted by the public, the lawmakers will have to lift it from the existing regulations.

This study was conducted using two approaches. First, the doctrinal legal research, to predict some of the norms relating to capital punishment, both internationally accepted norms and the norms contained in the laws and regulations in Indonesia. Simultaneously examine some thoughts on the philosophy of the death penalty. The second approach is non-doctrinal legal research by examining the sociological aspects of the literature and obtained from the observation.

\section{B. Discussion}

\section{Juridical Aspects}

In Article 6 of the International Covenant on Civil and Political Rights (ICCPR), it is stated that no one should be subjected to torture, mistreatment, or cruel, inhuman, or degrading treatment. This article is tangent to the death penalty. The death penalty is considered a form of execution of cruel and inhuman punishment. It is associated with the perspective of Human Rights, so that the implementation of the death penalty, which claimed the lives of offenders, violating these rights. These circumstances cannot be confronted in opposition. The provision of capital punishment is usually based on

\footnotetext{
${ }^{3}$ Masaki Ichinose, "The Death Penalty Debate: Four Problems and New Philosophical Perspectives", Journal of Practical Ethics 5, no. 1 (2017): 56-84, 56.
} 
consideration of the crimes committed, and the crime also violates other people's lives. This means that people who commit these crimes also have violated the right to life. These things ought to be seen in a balanced manner, not to give a slanted view of the death penalty.

Article 6 of the ICCPR states that every human being has the inherent right to life on him. This right shall be protected by law. No one shall be deprived of his life arbitrarily. The context of the arbitrarily can be understood from the provision of the following in Article 6 of the ICCPR, which states that for countries which have not abolished the death penalty, the death sentence can only be imposed for the most severe crimes by the law applicable at the time of the crime. The penalty can only be carried out based on a final decision rendered by a competent court. This provision can be interpreted that as long as there is a crime that threatened the death penalty in a country, governed by the law of the country, in the sense that the Act is a legal product that is agreed upon by all parts of the country, the death penalty imposed cannot be regarded as an arbitrary action.

As mentioned in other provisions, every person who has been sentenced to death has the right to ask for forgiveness or punishment replacement. Amnesty, pardon, or replacement can be given the death penalty in all cases. This provision reinforces the legality of the death penalty, which, when applied, then the person who imposed the death penalty can apply for remission or reimbursement penalties. This means that the death penalty is legal and does not violate any rights of all are applied fairly. As mentioned in other provisions, the death penalty should not be made against a person aged under 18 years. Restrictions against offenders under 18 years are equal to allowing the death penalty for a person over the age of 18 years, which means the death penalty is not prohibited from applying.

Some of the above provision is a provision in the ICCPR which in principle still allows the death penalty subjected throughout regulated in the law (legal) according to the needs of the country concerned. This led to the State, which still provides the death penalty for the perpetrators of certain crimes, cannot be regarded as a country of human rights offenders.

In addition to the ICCPR, any provision of derivatives in the form of an optional protocol, which is an optional protocol regarding the authority and shape monitoring mechanism for the implementation of the ICCPR in States parties as well as the procedure for complaints of victims of human rights violations to the human rights committee. The next optional protocol on the States parties enjoined to take all necessary measures to abolish the death penalty under its jurisdiction. However, because it is a choice (optional), then the countries that have ratified the ICCPR are not necessarily required to ratify the optional protocol so that the obligations in the optional protocol becomes mandatory for countries that do not ratify it. In connection with the death penalty, in the ICCPR, as described earlier, the death penalty is imposed based 
on legal throughout the implementation of the law (not arbitrary). Countries, including Indonesia, which still applies the death penalty, do not violate the convention. Being violated the convention when it ratified the optional protocol but still apply the death penalty. Indonesia, in this position, does not participate in ratifying the optional protocol, which requires abolishing the death penalty, so the rules regarding the death penalty in Indonesia are legal.

As a country that ratified the ICCPR, Indonesia, when the view still requires the death penalty to punish the perpetrators of the crime, then it is time to manifest the provisions on the death penalty in the laws. In practice, Indonesia has carried it out. In the Universal Declaration of Human Rights (UDHR) itself, it is also stated that no one should be tortured or abused, mistreated, or punished or insulted. ${ }^{4}$ Terms that are used as a reference of the ICCPR concerning the death penalty are categorized as an inhuman punishment and the explanation of the punishment that should not be arbitrary. If this is set in legislation on the category of inhuman or arbitrary, it will be unlikely acceptable. This certainly is not in accordance with the Universal Declaration of Human Rights o December 10, 1948, which provided the initial framework for the development of what is now a sophisticated and complex system of international human rights law. It is sometimes stated that the sentence is not even a matter of human rights. ${ }^{5}$

In the Human Rights Act No. 39 of 1999 set of laws on the right to life, freedom from torture, the right to personal freedom, freedom of thought and conscience, freedom of religion, the right not to be enslaved, the right to be recognized as a person and equality before the law, and the right not to be prosecuted based on retroactive law is the right of human rights that cannot be reduced under any circumstances and by anyone. The provision is also considered as the basis for the death penalty forbidden to execute. Although there is no explanation of the provision, it is clear that Article 9 of the Law did not mention the ban to give the death penalty for the perpetrators.

Given some juridical considerations above, it can be seen that the international regulations still give authority to the states to use the death penalty as a means of punishment. Throughout the death penalty is stipulated in the provisions of a State's law, the death penalty cannot be called arbitrary. As a country that is still governing the death penalty, Indonesia cannot be considered a country was violating human rights when implementing it because the death penalty has been regulated in Indonesian legislation. The difference lies in the criminal law legislation currently in effect, the death penalty in place as the principal criminal, so it seems to be something that is always going to be done, even though the death penalty is infrequently sentenced in Indonesia. On the bill of Indonesia's criminal code, the death

\footnotetext{
${ }^{4}$ Article 5, Universal Declaration of Human Right.

5 William A Schabas, The Abolition of Capital Punishment from an International Law Perspective (England: Cambridge University Press, 2003), 3.
} 
penalty is placed as an alternative, so it will be given only to crimes that reserve the right to be given the death penalty. The death penalty regulation in the Bill of Indonesia's Criminal Code is by far an administrative aspect of the death penalty. Therefore it established that the legislature represents the needs of Indonesian society.

In the Criminal Justice Reform Institute report (ICJR) in $2017^{6}$ stated that the new order (1966-1998), the inclusion of the death penalty is used in an attempt to achieve political stability in order to secure the development agenda. At this time, someone with narcotics crimes is regarded as subversive efforts. Corruption in this period never charged with using Law 11/PNPS/1963 on subversion that included death threats, although, at this time, the evil of corruption itself is not punishable by death. Giving the indictment to include the penalty of death is what it contains elements of human rights violations because it is not contained in the legislation governing such offences. But today, corruption in the laws and regulations in Indonesia also carries the death penalty, which means when applied to corruption, it does not violate human rights, in accordance with the ICCPR. In Indonesia, at this time, most of the death penalty in several cases, including murder, narcotics, and terrorism. Although in the legislation, there are also crimes of corruption and some other major crimes but has never got sentenced into the death penalty.

\section{Sociological Aspect}

Radelet said, comparing the effects of retributive of the death penalty with the effect retributive of life in prison without parole (LWOP) and found the effects of retributive incremental (additional) of the death penalty is often punished more innocent people than imprisonment for life, Proponents of the death penalty are basing their support for the levy need to be aware that the levy affects the guilty and the innocent. ${ }^{7}$ It should be noted further, as it may affect the public's view on the death penalty. In perspective impose the death penalty, of course, is not easy. Although the normative already qualified to be given the death penalty, the death penalty is still an option that is not easy. As Falco views, to strengthen the foundation for capital punishment, it is necessary to examine the forming factors of public opinion about using the death penalty. ${ }^{8}$

\footnotetext{
${ }^{6}$ http://icjr.or.id/hukuman-mati-di-indonesia-dari-masa-ke-masa/2017, Accessed on January 30, 2020.

${ }^{7}$ Michael L Radelet, "The Incremental Retributive Impact of a Death Sentence Over Life Without Parole", University of Michigan Journal of Law Reform 49, no. 4 (2016): 795-815, 796.

${ }^{8}$ Diana L Falco and Tina L Freiburger, "Public Opinion and the Death Penalty: A Qualitative Approach", The Qualitative Report 16, no. 3 (2011): 830-847, 831.
} 
The death penalty is closely related to retaliation. When considering the theory of punishment, then retaliation is acceptable, so it cannot be seen as something that is not human. When discussing the history of the administration of justice, it appears that the punishment by the State is a substitute for personal vengeance. Some perspectives on retaliation may be taken as follows. In many societies, crime or injustice retributive anger raises the wider community. Retaliation means that the guilty pay for his mistakes because people who make mistakes wants to avenge himself, the State considers it is necessary to inflict pain or injury (censure) on the guilty to prevent personal retaliation. ${ }^{9}$ This is the role of law as a means of prevention of other criminal acts. When the law cannot provide a sense of a fair play role for the public, it is feared that it will bring personal retaliation. It needs to be addressed concerning the innocent people that given the death penalty. NAACP Criminal Justice Department said in a report if an innocent person can be convicted, sentenced to death, and executed, the criminal justice system cannot be trusted to differentiate the innocent from the guilty. Between 1973 and 2016, 156 people were sentenced to death and later found not guilty.

During the same period, 1142 people have been executed. This means that for every ten people who were executed, more than one person had been released. This number does not include people who were executed even though there is strong evidence of innocence, or for whom evidence is found innocent after being executed ${ }^{10}$ of countries that apply the death penalty in the system of sanctions, when adhered to an international agreement that would impose the death penalty in accordance with existing rules in their own country, Indonesia, in terms of applying the death penalty to be referring to laws that apply in Indonesia. It can be said that the application of the death penalty in Indonesia does not stray from the criminal law enforcement system. A person sentenced to death is indeed a person who is eligible to receive the death penalty.

In Indonesia, the views Institute Criminal Justice Reform (ICJR) ${ }^{11}$ which states that in the new period (1966-1998), the death penalty's inclusion is used to achieve political stability to secure the development agenda. At this time, narcotics criminals are regarded as subversive efforts. Corruption in this period never charged with using the Law 11/PNPS/1963 on subversion that included death threats, although, at this time, the evil of corruption itself is not punishable by death. Some legislation which includes, among others, the death penalty and Means Crime Flights Flight and Atomic Energy. This note

\footnotetext{
${ }^{9}$ Neena Mary Philip, "Crime and Society A Sociological Analysis of Criminal Behaviour Among Youth in Alappuzha District", A Thesis, Mahatma Gandhi University, (2017), 117-144. ${ }^{10}$ Criminal Justice Departement NAACP, NAACP Death Penalty Fact Sheet (United States: NAACP, 2017), 49-50.

11 http://icjr.or.id/hukuman-mati-di-indonesia-dari-masa-ke-masa, Accessed on February 1, 2020 .
} 
outlines that given the death penalty in the context of political stability. Of course, the foundation cannot be justified because it includes removal efforts of lives by arbitrary.

During the reform period, the inclusion of the death penalty in the legislation characterized by the presence of reason "emergency" reasons ranging from "emergency" to "child protection" and also scale the number of victims who became an important reason to give a response weighting for the sake of the stability of national penalties. There are some of the most popular motives for the death penalty in Indonesia. The death penalty has a higher effectiveness rate than other penalties. Besides having a chilling effect (shock therapy), the death penalty is also considered to be more efficient. The death penalty is also used so that there is no vigilantism in the community. These considerations must be accounted for by the underlying by the persistence of the public's desire extensively on the use of the death penalty. For severe crimes that are detrimental to society at large, it seems natural that people also expect severe punishment for the perpetrators. This means that in this case, the death penalty is given top acts in the public's assessment is not to be tolerated for a given mediocre punishment.

However, considering the death penalty with a more efficient assessment needs to be seen as inhuman views. Although, in reality, Indonesia has experienced a severe financial burden on the offenders sentenced, the death penalty remains inappropriate functioned as an effective sanction. That view needs to be taken away by lawmakers. In the case of the death sentence given to people not doing vigilante, these considerations clearly refer to the community's needs. Psychological society judge a crime may be given a light sentence or weight, an assessment must be considered by the legislature to create a sense of justice in society and avoid people taking a stand-alone against an offence if the public does not give it sanction in accordance.

Giving the death penalty, in principle, is retaliation (retributive). Evil must be returned to the crime, and that person must be treated in a manner in which he dealt with others. An eye for an eye and a tooth for a tooth is considered natural justice rules. Although the system of personal revenge has been pressed, instincts and emotions are at the root of these feelings still exist in human nature. Therefore, according to this theory, the public's moral satisfaction from the penalty cannot be ignored. On the other hand, if the criminals are treated very softly, or even in the middle of the luxuries, such as the concept of reformative (and as actually happened in some prisons around the world, equipped with air conditioning, a private toilet, television), the spirit of revenge is not will be satisfied, and may find its way through personal retaliation. Therefore, punishment, rather than preventing crime, may indirectly promote it. ${ }^{12}$

${ }^{12}$ Neena Mary Philip, Loc.Cit. 
In anticipation of the incapability of the law to provide such a sense of justice in society, laws should be made according to the psychological condition of the local community. The psychological condition of a society cannot be regarded with others'. In regard to this concept, rationally, the penalty can be accepted by society at large, which means that the existing law is needed and wanted by the community at a time. The community is also changing by the time we are growing. This change will also create views on the punishment given to the perpetrators of crimes that will change. When originally a society and lawmakers agree to apply the death penalty, with the changes in society, the public and lawmakers agreed not to leave the death penalty on offenders again, and the death penalty is no longer applied. This means the development of society is also decisive to the application of the death penalty. If people still need the death penalty as a means to combat crime, the lawmakers should give the death penalty in the statute, but if people feel they no longer require the death penalty, then lawmakers should remove it.

There had been countries that initially had a death penalty as a punishment for the perpetrators of the crime but then got to revoke it. Or vice versa, some countries did not apply the death penalty at first but then set the death penalty as punishment. As in the Philippines, in 1987 abolished the death penalty, but in 1993, the Philippines revive the death penalty in the country, although later in 2006 got abolished back. In the European countries, which largely remove the death penalty from its legal system in the beginning, there is still a country that applies the death penalty. ${ }^{13}$ After the shift in values in society, giving rise to an agreement to no longer apply the death penalty, then by legislators and government, the death penalty was abolished.

In Indonesia, the imposition of capital punishment is often not straightly sentenced. Therefore many of the death row waiting for quite a long time. In fact, the time given to death row inmates to improve themselves while waiting for the implementation of the penalty. Even in the legislation governing the death penalty, the death penalty is given with strict limits. For example, the regulations concerning corruption, the culprit can be sentenced to death in certain circumstances, the State can be used as a reason weighting punishment for perpetrators of corruption, such as corruption of the funds earmarked for combating danger, national disasters, countermeasures widespread social unrest, economic and monetary crisis management, and control of corruption itself. ${ }^{14}$

This is consistent with Simons' observation, who see the character and beliefs of indigenous people (Indonesia), Simons did not agree to the retention

\footnotetext{
${ }^{13}$ Barda Nawawie Arief, "Ancaman Pidana Mati Tindak Pidana Korupsi Dalam Peraturan Perundang-Undangan", Masalah-Masalah Hukum 42, no. 1 (2013): 23-33, 25, DOI: 10.14710/mmh.42.1.2013.23-33.

${ }^{14}$ Explanation of Law No. 31 of 1999 concerning Corruption Eradication.
} 
of the death penalty in Weetboek van Sraftrecht (which was later taken into the Criminal Code). However, Simons could receive the death penalty if they are viewed as an emergency act in exceptional circumstances that are retained in the Criminal Code..$^{15}$ That is for emergencies, the death penalty can still be maintained. In addition, according to Simons, the death penalty when administered as a last resort, it should be well regulated in writing. ${ }^{16}$ As a comparison, capital punishment persists in Japan partly because it performs some positive functions. It is a practical instrument for prosecutors that allows them to "harness the power of death in the pursuit of professional objectives".

Furthermore, in one of the states in the United States, Maryland, 14 prior studies have consistently shown that the death penalty increases the state budget. If the death penalty were abolished, those dollars could be used in various positive ways-including returning them to Delaware taxpayers. However, hard-won experience suggests that the only way for those gains to be realized is to reallocate the public's money now. When savings such as these can be anticipated, the best course of action is to take that money off the table. If we wait, the money will be spent for other purposes before there can be any public debate. ${ }^{17}$ Abolishing the death penalty with the consideration of spending a large fee, carried out so that the costs incurred can be used for other financings. However, in Indonesia, when it comes to financing prisoners, putting prisoners in jail for a long time is an act that costs the state budget.

In the process of implementation of the penalty, in Indonesia, there is much space to lighten the punishment for the convict. The convict should also own the right to obtain leniency to death. It could be in a period waiting for the implementation of the death penalty, as it is considered to have such good behaviour and show improved behaviour, and show remorse, then naturally also entitled to leniency - for example, the death penalty into imprisonment. Therefore, the convicts could have the chance of getting to life again, although a reduced sentence on death row is unprecedented in Indonesia. It is intended, a person sentenced to death was given the opportunity to improve themselves, promised themselves not to repeat the crimes they committed, and be better. Changes to these death-row inmates themselves should also be considered by law enforcement to consider the commute a death row inmate so that the chance of his life back.

Some of the above show that the death penalty will be given on mature consideration, and the actions that violate human values see the convict social conditions and considers behaviour changes. Such restrictions are the areas for the implementation of the death penalty in Indonesia. According to

\footnotetext{
${ }^{15}$ JE Sahetapy, Ancaman Pidana Terhadap Pembunuhan Berencana (Malang: SETARA Press, 2009), 37.

${ }^{16}$ Ibid.

17 John K Roman, Costs of the Death Penalty (Judiciary Committee Delaware Senate, 2013), 2.
} 
Venturi, Indonesia also views several major reasons for the death penalty, among other things: ${ }^{18}$ first, the death penalty is a more effective deterrent and therefore prevents crime better. With the death penalty, others were about to commit a similar crime is expected not to commit the crime. Although it is not guaranteed, more severe sanctions were allowed as a means of crime prevention. Second, the death penalty is more effectively immobilizing offenders. Perpetrators, in principle, still manage to have the desire to commit the crime again after release. Sentencing the death penalty will stifle the desire. The death penalty believed may provide beneficial effects for the social order within the community. It thus also becomes a consideration in Indonesia still using the death penalty as a punishment for the perpetrators. The third, Indonesia still considers that the death penalty for perpetrators of crimes is not a violation of human rights, but rather to respect human rights itself, namely for victims of crime.

\section{The Death Penalty is Not Ideology}

Executing the death penalty is not associated with any particular ideology. Even in countries that still apply the death penalty, consisting of the different countries in ideology. Data released by the world population review shows that 14 countries often impose the death penalty, which are China, Bangladesh, Egypt, Ethiopia, India, Indonesia, Iran, Japan, Nigeria, Saudi Arabia, South Korea, Taiwan, Sri Lanka, and the United Nations. There are no ideological similarities among the countries mentioned above. Even these countries are a country with a large population globally, such as China, India, the USA, and Indonesia. This means that the application of the death penalty in many countries today, including Indonesia, can be said the need of these countries in order to maintain order and security of society. There are no great upheavals in society in these countries that prove that the death penalty is still considered necessary by the communities themselves, and therefore still applied. Countries that have abolished the death penalty must also take into account the needs of its community so that lawmakers can take action.

\section{Conclusion}

The law and the application of the death penalty in Indonesia until now are still needed. It is considering that there are still many crimes that undermine humanity's values or the crimes that harm the State and crackdown on society's corruption. This situation must be addressed with sanctions balanced by the crime and the impact of the crime. Although Indonesia still applies the death penalty, it cannot be said that Indonesia is human rights

18 Giulio Carlo Venturi, "The Death Penalty FUNDAMENTALS AND SYSTEMS OF POSITIVE LAW", "Non Occides" Exodus 20, no. 13 (2017): 1-18, 5. 
violator country because the death penalty is given on the basis of a clear legal basis the legislation, as well as assessing the community still needed. The death penalty also is given not as a primary choice, but as a last resort. The magnitude of the deterrent effect of the death penalty, including the possibility of no effect, will depend on the scope of legal authority for its use and how legal authority is actually managed. ${ }^{19}$

\section{References}

Arief, Barda Nawawie. "Ancaman Pidana Mati Tindak Pidana Korupsi Dalam Peraturan Perundang-Undangan", Masalah-Masalah Hukum 42, no. 1, 2013: 23-33, DOI: 10.14710/mmh.42.1.2013.23-33.

Chan, Janet., Oxley, Deborah. "The Deterrent Effect of Capital Punishment :

A Review of the Research Evidence". Crime and Justice Bulletin, no. 84, 2004: 1-24.

Criminal Justice Departement NAACP, NAACP Death Penalty Fact Sheet. United States: NAACP, 2017.

Falco, Diana L., Freiburger, Tina L. "Public Opinion and the Death Penalty: A Qualitative Approach", The Qualitative Report 16, no. 3, 2011: 830847.

http://icjr.or.id/hukuman-mati-di-indonesia-dari-masa-ke-masa/2017,

Accessed on January 30, 2020.

Ichinose, Masaki. "The Death Penalty Debate: Four Problems and New

Philosophical Perspectives", Journal of Practical Ethics 5, no. 1, 2017: 56-84.

International Covenant on Civil and Political Right (ICCPR).

Johnson, David T. "Retention and Reform in Japanese Capital Punishment PUNISHMENT", U. MICH. J. L. REFORM 853, no. 49, 2016: 853-889.

Nagin, Daniel S., Pepper, John V. Deterrence and the Death Penalty. Washington: The National Academies Press, 2012.

Radelet, Michael L. "The Incremental Retributive Impact of a Death Sentence Over Life Without Parole", University of Michigan Journal of Law Reform 49, no. 4, 2016: 795-815.

Roman, John K. Costs of the Death Penalty. Judiciary Committee Delaware Senate, 2013.

Roy, Gargi. "Is Capital Punishment Acceptable?". International Journal of Humanities and Social Science 4, no. 2, 2014: 95-98.

Sahetapy, JE. Ancaman Pidana Terhadap Pembunuhan Berencana. Malang: SETARA Press, 2009.

Schabas, William A. The Abolition of Capital Punishment from an International Law Perspective. England: Cambridge University Press,

19 Daniel S Nagin, John V Pepper, and (editors), Deterrence and the Death Penalty (Washington: The National Academies Press, 2012), 27. 
2003.

Venturi, Giulio Carlo. "The Death Penalty FUNDAMENTALS AND SYSTEMS OF POSITIVE LAW", "Non Occides" Exodus 20, no. 13, 2017: 1-18. 
